\title{
Synthesis and evaluation of bisulfate/mesylate-conjugated chlortetracycline with high solubility and bioavailability
}

DENG LIU

PEIXING CHEN

XU YANG

JIANHUA WANG*

Key Laboratory of Biorheological Science and Technology, Ministry of Education Bioengineering College, Chongqing University, Chongqing, 400044 People's Republic of China
Accepted January 24, 2020

Published online April 2, 2020

\begin{abstract}
The aim of this work is to improve the solubility and bioavailability of chlortetracycline and the function of the immune response. Chlortetracycline bisulfate and chlortetracycline mesylate were successfully synthesized and characterized with several techniques, including spectroscopy, chromatography and mass spectrometry, which demonstrated that the $\mathrm{C}_{4}$-dimethylamino group of chlortetracycline can accept a proton from sulfuric acid and methanesulfonic acid to form the corresponding salts. In addition, chlortetracycline bisulfate and chlortetracycline mesylate were more soluble in water than chlortetracycline hydrochloride, but the antibacterial activity was not enhanced. The influences of chlortetracycline hydrochloride, chlortetracycline bisulfate and chlortetracycline mesylate on chlortetracycline and immunoglobulin concentrations in mouse serum were also investigated. These results suggested that the chlortetracycline bisulfate and chlortetracycline mesylate have good bioavailability and strong immune response and have potential applications in animal breeding and formulation technologies.
\end{abstract}

Keywords: chlortetracycline, pharmaceutical salt, solubility, bioavailability, antibacterial activity, immunoglobulin

Tetracyclines (TCs) are a family of structurally related compounds that include tetracycline (TC), oxytetracycline, doxycycline, minocycline, chlortetracycline (CTC), sancycline, and methacycline. CTC, which is the first member of TCs, was discovered by Duggar (1). It has a broad spectrum of antibiotic activity against a wide range of Grampositive and Gram-negative bacteria, including rickettsiae, enterococci and mycoplasma gallisepticum $(2,3)$. Therefore, it has been widely used in clinical applications to treat a variety of infectious microorganisms. TCs are usually used alone to treat diseases at therapeutic levels and promote animal growth and feed efficiency at subtherapeutic levels $(4,5)$; additionally, the combination of probiotics could improve nursery pigs' performance, but there were no consistent benefits of feeding them either probiotics alone or in the combination with CTCs (6).

\footnotetext{
*Correspondence, e-mail: jhwangcqu@gmail.com
} 
D. Liu et al:: Synthesis and evaluation of bisulfate/mesylate-conjugated chlortetracycline with high solubility and bioavailability, Acta Pharm. 70 (2020) 483-498.

As an animal feed additive, there are two types of CTC products on the market, chlortetracycline hydrochloride $(\mathrm{CTC} \times \mathrm{HCl})$ and CTC premix (CTC calcium complex), which have been used in poultry and livestock industries to promote animal growth and prevent/treat animal diseases. However, shortcomings, such as its poor solubility and low bioavailability, have limited the clinical application to some extent (7). Therefore, it is a challenge to improve the solubility without compromising the stability and other performance characteristics of CTC. One of the common procedures to improve the aqueous solubility of a drug is salt formation using a suitable counter ion (8). For example, when hexamidine diisethionate was converted to hexamidine dihydrochloride, the solubility and stability were improved because the salt is an aromatic diamidine with trypanocidal activity (9). Ciprofloxacin and norfloxacin can react with mesylate, gluconate and glycolate to form several organic salts to improve their solubility in comparison to that of their hydrochloride salts or free fluoroquinolones (10).

CTC contains a 4-ring carbocyclic structure (11), which has multiple ionizable functional groups. The CTC structure contains the tricarbonyl system $\left(\mathrm{C}_{1}, \mathrm{C}_{2}-\mathrm{CONH}_{2}, \mathrm{C}_{3}\right)$, ketophenolic hydroxyl groups $\left(\mathrm{C}_{10}-\mathrm{C}_{12}\right)$ and a dimethylamino group, which cause CTC to undergo protonation-deprotonation reactions depending on the $\mathrm{pH}$ of aqueous solutions. In addition, CTC has three acid dissociation constants $\left(\mathrm{p} K_{\mathrm{a}}=3.3,7.55\right.$ and 9.3). Therefore, CTC can be present in its cationic, zwitterionic or anionic form under acidic, moderately acidic to neutral or alkaline conditions, respectively (Fig. 1) (12). Hydrochloric acid is commonly used to convert organic alkaline drugs to their salts. The dimethylamino group of CTC can accept the proton from hydrochloric acid to form the $\mathrm{CTC} \times \mathrm{HCl}$ salt. The reaction between an alkaline drug and acid is expected to form a salt if the difference of the base and acid, $\Delta \mathrm{p} K_{\mathrm{a}}=\mathrm{p} K_{\mathrm{a} \text {-base }}-\mathrm{p} K_{\mathrm{a} \text {-acid }}$, is greater than 3. This is well known as a "rule of three". When the $\Delta \mathrm{p} K_{\mathrm{a}}$ value is over 4 , the reaction tends to exclusively form salts $(13,14)$. The $\Delta \mathrm{p} K_{\mathrm{a}}$ values between the dimethylamino group $\left(\mathrm{p} K_{\mathrm{a}}=9.3\right)$ of CTC and hydrochloric acid $\left(\mathrm{p} K_{\mathrm{a}}=\right.$ $-6)$, sulfuric acid $\left(\mathrm{p} K_{\mathrm{a}}=-3\right)$ and methanesulfonic acid $\left(\mathrm{p} K_{\mathrm{a}}=-1.2\right)$ are equal to 15.3, 12.3 and 10.5, respectively, which indicates the easy formation of an ionic salt.

Chlortetracycline salts almost always contain small amounts of impurities, such as 4-epichlortetracycline (4-epiCTC), tetracycline (TC) and 4-epitetracycline (4-epiTC), especially when they are out-of-date or stored under high temperature and humidity. The bioactivity of these impurities is lower than that of CTC, and their biotoxicity to livestock is increased. Furthermore, these impurities may lead to TCs residues in animal tissues when poultry and livestock are treated with TCs (15-21). Anadon et al. (19) reported that mean values of CTC plus 4-epiCTC in kidney, liver and muscle tissue were 835.3, 192.7, and 126.3 $\mu \mathrm{g} \mathrm{kg}^{-1}$, respectively, after 1 day of treatment with CTC in the fattening process of chickens. CTC can also be metabolized and transferred to egg albumin and egg yolks from hens (15). It was reported that 5 and 9 days were needed to eliminate CTCs in albumin and yolk, respectively, after medicated feed withdrawal (20). Due to the lack of proper guidance for use, the majority of TCs are excreted to the environment through urine and feces, and most CTCs are retained in the manure or soil directly beneath the manure application site (22). CTC retained in the soil can be taken up by plants $(23,24)$ and has a negative effect on soil enzyme activities, including those of urease and dehydrogenase (25). Moreover, it could be a potential threat to human health when meats and plants contaminated with TCs are eaten.

In this study, two new CTC salts were synthesized using sulfuric acid and methanesulfonic acid. The structures of the two newly synthesized salts were characterized by 
high-performance liquid chromatography (HPLC), ion chromatography (IC), thermal analysis and spectroscopy. The solubility of the new salts was compared with that of $\mathrm{CTC} \times \mathrm{HCl}$ and their antibiotic activities were investigated with Gram-negative and Gram-positive bacteria. The in vivo responses of the immune system to $\mathrm{CTC} \times \mathrm{HCl}$, chlortetracycline bisulfate $\left(\mathrm{CTC} \times \mathrm{H}_{2} \mathrm{SO}_{4}\right)$ and chlortetracycline mesylate $\left(\mathrm{CTC} \times \mathrm{CH}_{3} \mathrm{SO}_{3} \mathrm{H}\right)$ were also tested. The results showed a high bioavailability of $\mathrm{CTC} \times \mathrm{H}_{2} \mathrm{SO}_{4}$ and $\mathrm{CTC} \times \mathrm{CH}_{3} \mathrm{SO}_{3} \mathrm{H}$ in in vivo models for oral absorption as we expected.

\section{EXPERIMENTAL}

\section{General}

Differential scanning calorimetry (DSC) and thermogravimetric analysis (TGA) of CTC salts were performed with a NETZSCH DSC 404 F3 Pegasus ${ }^{\circledR}$ equipped with a refrigerated cooling system (liquid nitrogen cooling) (Germany). The CTC salts ( $5 \pm 0.01 \mathrm{mg}$ ) were heated in aluminum sample holders and scanned at $10^{\circ} \mathrm{C} \mathrm{min}{ }^{-1}$ in the range of $50-$ $500{ }^{\circ} \mathrm{C}$ under a nitrogen atmosphere. The data were analyzed by Proteus ${ }^{\circledR}$ software. ${ }^{1} \mathrm{H}$ nuclear magnetic resonance $\left({ }^{1} \mathrm{H}\right.$ NMR) spectra were acquired using an Agilent-NMRvnmrs600 instrument. The CTC salts were dissolved in dimethyl sulfoxide- $d_{6}$ (DMSO- $d_{6}$ ) with tetramethylsilane (TMS) as a reference. The conventional powder X-ray diffraction (PXRD) method was used for qualitative phase analysis. A Rigaku D/Max2500pc diffractometer was used with $\mathrm{Cu}$ radiation. The maximum wattage was $18 \mathrm{~kW}$. The voltage and amperage of the $\mathrm{Cu}$ tube were set at $40 \mathrm{kV}$ and $150 \mathrm{~mA}$, respectively. Solid CTC salts were scanned between $10^{\circ}$ and $90^{\circ}$ in $2 \theta$ with a rate of $4^{\circ} \mathrm{min}^{-1}$. The ultraviolet-visible (UV) absorption spectra were recorded over 200-500 $\mathrm{nm}$ with a Shimadzu UV1800. The infrared (IR) spectra of $\mathrm{CTC} \times \mathrm{HCl}, \mathrm{CTC} \times \mathrm{H}_{2} \mathrm{SO}_{4}$ and $\mathrm{CTC} \times \mathrm{CH}_{3} \mathrm{SO}_{3} \mathrm{H}$ were recorded over the region of $400-4000 \mathrm{~cm}^{-1}$ with a Braic WQF-510A spectrophotometer. The samples were examined in $\mathrm{KBr}$ pellets. A mass spectrometer (MS) (Waters Acquity SQ Detector) equipped with an ESI source was used in both positive and negative ion modes. The solid $\mathrm{CTC} \times \mathrm{HCl}$, $\mathrm{CTC} \times \mathrm{H}_{2} \mathrm{SO}_{4}$ and $\mathrm{CTC} \times \mathrm{CH}_{3} \mathrm{SO}_{3} \mathrm{H}$ salts were dissolved in methanol. The electrospray voltage was $2.8(+/-) \mathrm{kV}$, and the desolvation temperature was $400{ }^{\circ} \mathrm{C}$. The cone gas flow rate and desolvation gas flow rate were set at 55 and $550 \mathrm{~L} \mathrm{~h}^{-1}$, respectively.

$\mathrm{CTC} \times \mathrm{HCl}$ was a gift from Pucheng Chia Tai Biochemistry Co. Ltd. (Fujian, China). Sulfuric acid was purchased from Eagle Chemical Reagent Co. Ltd. (Zhejiang, China). Methanesulfonic acid, isopropyl alcohol and 2-ethoxyethanol were purchased from Kelong (Chengdu, China) and stored in the dark environment. Methanol, ethanol and $n$-butanol were obtained from Chuandong Chemical Co. Ltd. (Chongqing, China). All other reagents for reactions and chromatography experiments were of analytical grade or HPLC grade.

\section{Synthesis}

Preparation of CTC neutral base. $-\mathrm{CTC} \times \mathrm{HCl}(8 \mathrm{~g})$ was added to $1000 \mathrm{~mL}$ of water and the mixture was stirred for $30 \mathrm{~min}$ at $18{ }^{\circ} \mathrm{C}$. The undissolved impurities were removed from the solution by filtration. Then, the $\mathrm{pH}$ of the solution was adjusted to 4.2 to obtain the precipitation of the CTC neutral base while the slurry was stirred for $1 \mathrm{~h}$. Finally, the solution was filtered and further washed with water and ethanol to obtain the CTC neutral 
base. The CTC neutral base was dried under vacuum at room temperature for $48 \mathrm{~h}$. The yield of the CTC neutral base was $87.9 \pm 1.8 \%$.

Preparation of $\mathrm{CTC} \times \mathrm{H}_{2} \mathrm{SO}_{4}$. - First, $5 \mathrm{~mL}$ of sulfuric acid $(50 \% \mathrm{~m} / \mathrm{V}$, ethylene glycol solution) was slowly added to $10 \mathrm{~mL}$ of a 2-ethoxyethanol and ethylene glycol (1:1) mixture solution that was chilled at $15^{\circ} \mathrm{C}$. After that, $5 \mathrm{~g}$ of the CTC neutral base was added to the solution, and the mixture was magnetically stirred for $2 \mathrm{~h}$ at $15^{\circ} \mathrm{C}$. Then, $20 \mathrm{~mL}$ of $n$-butanol was added, and the mixture was stirred for $15 \mathrm{~min}$ for crystallization. The reaction mixture was left at $4{ }^{\circ} \mathrm{C}$ for $2 \mathrm{~h}$ before filtration. The filtered product was further washed twice with $n$-butanol and once with isopropanol, and then dried under vacuum at room temperature for $48 \mathrm{~h}$ to obtain $\mathrm{CTC} \times \mathrm{H}_{2} \mathrm{SO}_{4}$, representing a yield of $64.6 \pm 5.5 \%$. A scanning electron microscopy (SEM) micrograph of $\mathrm{CTC} \times \mathrm{H}_{2} \mathrm{SO}_{4}$ is shown in Fig. 2a.

Preparation of $\mathrm{CTC} \times \mathrm{CH}_{3} \mathrm{SO}_{3} \mathrm{H}$. - Two milliliters of $50 \%$ methanesulfonic acid in methanol was slowly added to $8 \mathrm{~mL}$ of methanol that was chilled at $15^{\circ} \mathrm{C}$. Then, $5 \mathrm{~g}$ of the CTC neutral base was added to the solution, and the mixture was magnetically stirred for $1 \mathrm{~h}$ at $15^{\circ} \mathrm{C}$. Afterwards, $10 \mathrm{~mL}$ of ethanol was added, and the mixture was stirred for $20 \mathrm{~min}$ for crystallization. After chilling at $4{ }^{\circ} \mathrm{C}$ for $2 \mathrm{~h}$, the mixture was filtered, washed twice with ethanol and dried under vacuum for $48 \mathrm{~h}$ at room temperature to obtain the final product with a yield of $78.3 \pm 4.9 \%$. An SEM micrograph of $\mathrm{CTC} \times \mathrm{CH}_{3} \mathrm{SO}_{3} \mathrm{H}$ is shown in Fig. 2b.

\section{Quantitation analysis}

\section{HPLC analysis}

Reference substances of CTC (purity, 94.2\%), 4-epiCTC (purity, $90.1 \%$ ), TC (purity, 97.1 $\%$ ) and 4-epiTC (purity, $86.8 \%$ ) were purchased from the National Institutes for Food and Drug Control (China). To obtain the stock standard solutions, reference substances were dissolved in $0.01 \mathrm{~mol} \mathrm{~L}^{-1}$ hydrochloric acid and stored at $4{ }^{\circ} \mathrm{C}$ for 1 week before use. Standard solutions of $\mathrm{CTC} \times \mathrm{H}_{2} \mathrm{SO}_{4}$ and $\mathrm{CTC} \times \mathrm{CH}_{3} \mathrm{SO}_{3} \mathrm{H}$ were diluted in $0.01 \mathrm{~mol} \mathrm{~L}^{-1}$ hydrochloric acid. The CTC salts and impurities (4-epiCTC, TC, 4-epiTC) were measured using HPLC (Agilent 1260, USA) equipped with a C8 column (phenimenex, Luna 5u C8(2) 100A, $150 \times$ $4.60 \mathrm{~mm}$ ). HPLC analysis was performed following the techniques recommended by the product quality standard of chlortetracycline hydrochloride (CVP) (Q/PZSH 03-201), which was formulated by the Chia Tai Group. The ultraviolet detection wavelength was $280 \mathrm{~nm}$, and the injection volume was $20 \mu \mathrm{L}$.

\section{IC analysis}

To estimate the anion concentrations of $\mathrm{CTC} \times \mathrm{H}_{2} \mathrm{SO}_{4}$ and $\mathrm{CTC} \times \mathrm{CH}_{3} \mathrm{SO}_{3} \mathrm{H}$, solid CTC salts were dissolved in deionized water. Standard solutions of 5, 10, 20 and $40 \mu \mathrm{g} \mathrm{mL}$ hydrochloric acid, sulfate acid and methanesulfonic acid were prepared by diluting the corresponding stock solutions. Then, the solution of CTC salts was filtered through a 0.22 $\mu \mathrm{m}$ filter. The ion chromatography (ICS-5000, ThermoFisher, USA) was equipped with a self-regenerating suppressor (Dionex ASRS 300, $4 \mathrm{~mm}$ ) and a conductive detector and was used for determination of dissolved sulfate ions of the $\mathrm{CTC} \times \mathrm{H}_{2} \mathrm{SO}_{4}$ and the mesylate ions of the $\mathrm{CTC} \times \mathrm{CH}_{3} \mathrm{SO}_{3} \mathrm{H}$. An anion analytical column (Dionex IonPac AS11-HC, $250 \times 4 \mathrm{~mm}$ ) 
was used for separation. A $30 \mathrm{mM} \mathrm{NaOH}$ solution was used as the mobile phase with a

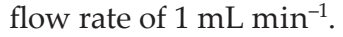

\section{Solubility tests}

An excess amount of CTC salt was added to water in an EP test tube for the determination of solubility. The test tube was placed in a thermostatically controlled water bath and vortexed with a Stuart Vortex Mixer SA8 (Bio Cote, U.K.) every $5 \mathrm{~min}$. The mixture was equilibrated for $30 \mathrm{~min}$ at $25^{\circ} \mathrm{C}$ to obtain a saturated solution. Then, the mixture was centrifuged with an Eppendorf 5430R centrifuge (Eppendorf, Germany) at $5000 \mathrm{rpm}$ for $5 \mathrm{~min}$ at $25^{\circ} \mathrm{C}$. Finally, the supernatant was diluted, and the concentration of the active compound was measured using HPLC.

\section{Biological evaluations}

Antibacterial activity. $-\mathrm{CTC} \times \mathrm{HCl}, \mathrm{CTC} \times \mathrm{H}_{2} \mathrm{SO}_{4}$ and $\mathrm{CTC} \times \mathrm{CH}_{3} \mathrm{SO}_{3} \mathrm{H}$ were tested for growth inhibitory activity against the bacteria Bacillus cereus ATC11778, Staphylococcus aureus ATCC6538 and Escherichia coli ATCC11775 in vitro. The final concentrations of the antibiotics were $1.07 \times 10^{-1}, 5.36 \times 10^{-2}, 2.68 \times 10^{-2}, 1.34 \times 10^{-2}, 6.70 \times 10^{-3}, 3.35 \times 10^{-3}, 1.67 \times 10^{-3}$, $8.37 \times 10^{-4}, 4.18 \times 10^{-4}, 2.09 \times 10^{-4}, 1.05 \times 10^{-4}$ and $5.23 \times 10^{-5} \mu \mathrm{mol} \mathrm{mL} \mathrm{m}^{-1}$. Bacterial strains were cultured in nutrient broth at $37^{\circ} \mathrm{C}$. The growth was recorded after incubation for $24 \mathrm{~h}$ and $48 \mathrm{~h}$ to test the minimal inhibitory concentration (MIC) and minimum bactericidal concentration $(M B C)$, respectively.

Immune regulation in vivo. - A total of 56 SPF level Kunming mice (KM) were randomly assigned to one of seven groups. The control group did not receive any treatment and was used to determine the validation criteria of any analytical method. The treatment groups of $\mathrm{CTC} \times \mathrm{HCl}, \mathrm{CTC} \times \mathrm{H}_{2} \mathrm{SO}_{4}$ and $\mathrm{CTC} \times \mathrm{CH}_{3} \mathrm{SO}_{3} \mathrm{H}$ were fed orally with $\mathrm{CTC}$ at a nominal dosage of $50 \mathrm{mg} / \mathrm{kg}$ BW/day for 42 consecutive days. Blood samples were collected from the eyes of the mice after 21 and 42 days. All blood samples were centrifuged with an Eppendorf 5430R centrifuge (Eppendorf, Germany) at $2000 \mathrm{rpm}$ for $12 \mathrm{~min}$, and the supernatant serum was harvested and stored at $-20^{\circ} \mathrm{C}$ until analysis. The concentration of CTCs in serum was analyzed with a CTC ELISA kit (Reagen, RND 99050). The immunoglobulin (IgM, IgG and IgA) levels in the serum of mice treated with CTCs were analyzed. All ELISA kits were purchased from Abcam (ab133047 IgM Mouse ELISA kit v2, ab157719 IgG Mouse ELISA kit v2 and ab157717 IgA Mouse ELISA kit v3).

\section{RESULTS AND DISCUSSION}

\section{Identification of the interaction between CTC and acids}

The structures of the new CTC salts were confirmed by ${ }^{1} \mathrm{H}$ NMR, PXRD, UV, IR, MS and thermal analysis, and the data are given in Table I. The atom numbering used in the current study is indicated in Fig. 1.

The ${ }^{1} \mathrm{H}$ NMR spectra of the different CTC salts displayed intense resonances near 2.9 ppm attributable to the common $\mathrm{C}_{4}$-dimethylamino group (26). The $\mathrm{N}$-protonation led to a 


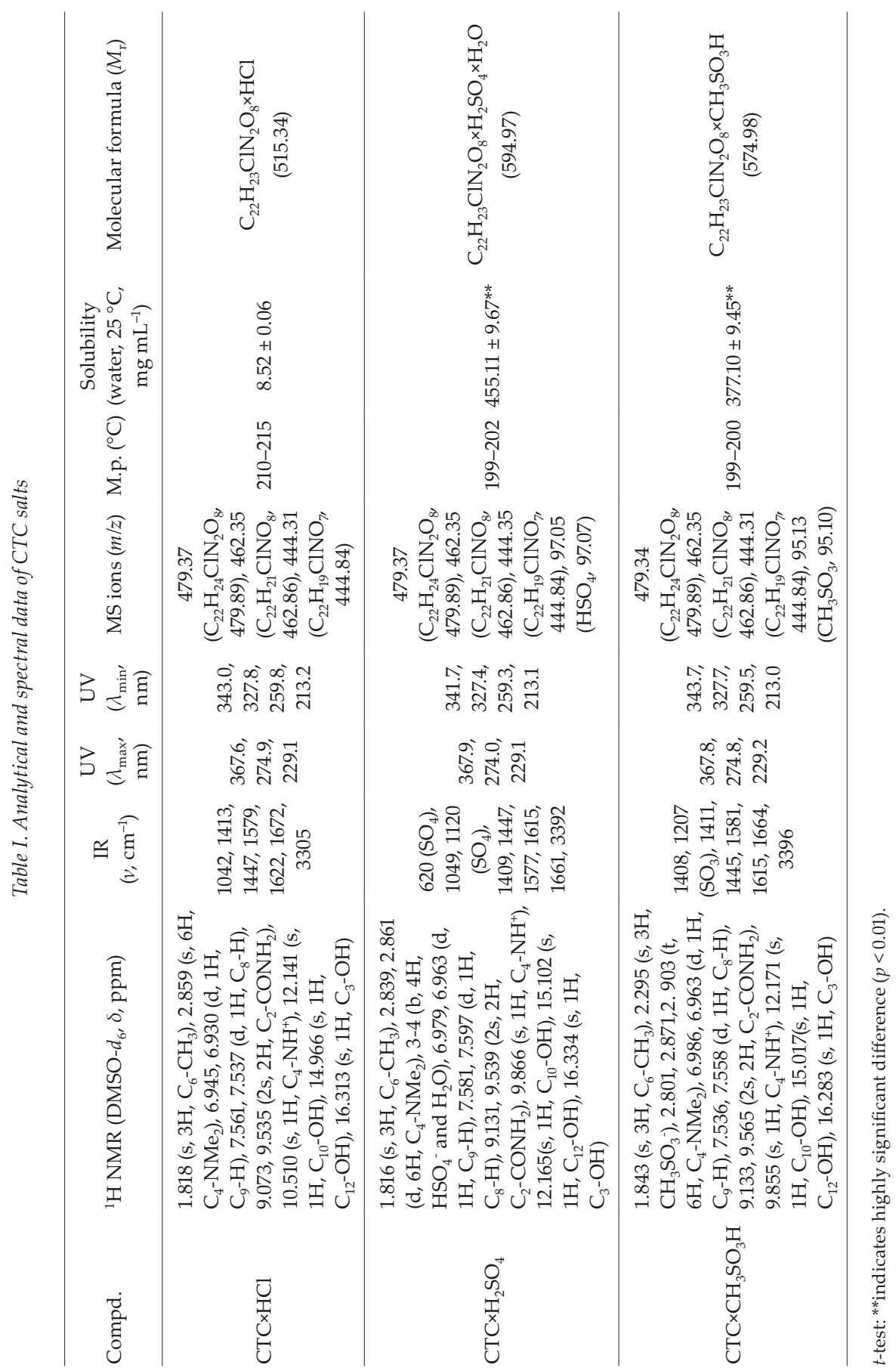




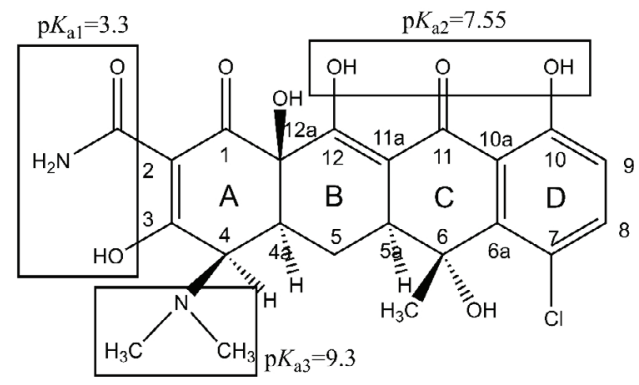

Fig. 1. Chemical structure of CTC and the $\mathrm{p} K_{\mathrm{a}}$ values.

pronounced downfield shift of $\mathrm{N}$-methyl resonances from 2.6 to $2.9 \mathrm{ppm}$ in CTC. The six protons of the $\mathrm{C}_{4}$-dimethylamino group in the hydrochloride salt were observed as a single peak that occurred at $2.859 \mathrm{ppm}$. These protons were split into multiple peaks in the sulfate and mesylate salts in the field near $2.859 \mathrm{ppm}$. The chemical shift of the ammonium proton was at a higher field because the proton was in the deshielded area. The absorption of $\mathrm{C}_{3^{-}}$ hydroxyl was appeared as a broad peak, near $16.3 \mathrm{ppm}$. The chemical shift of the ammonium proton in $\mathrm{CTC} \times \mathrm{HCl}, \mathrm{CTC} \times \mathrm{H}_{2} \mathrm{SO}_{4}$ and $\mathrm{CTC} \times \mathrm{CH}_{3} \mathrm{SO}_{3} \mathrm{H}$ was $10.510,9.866$ and 9.855 ppm, respectively (Fig. S1), because the different anions affected the electromagnetic environment of the ammonium proton differently. For the CTC salts, proton transfer from sulfuric acid and methanesulfonic acid to the $\mathrm{N}$-atom of the dimethylamino group were easily recognized. The $\mathrm{C}_{2}$-amide protons of $\mathrm{CTC} \times \mathrm{HCl}$ had broad resonances at 9.1 and 9.5 ppm, which was in agreement with the same observation for the chemical shift in the spectra of the $\mathrm{CTC} \times \mathrm{H}_{2} \mathrm{SO}_{4}$ and $\mathrm{CTC} \times \mathrm{CH}_{3} \mathrm{SO}_{3} \mathrm{H}$ compounds. This could have implied that the amide group did not participate in the salt formation reactions. For the $\mathrm{C}_{10}-\mathrm{C}_{12}$ ketophenolic hydroxyl groups, the $\mathrm{C}_{10}$ - and $\mathrm{C}_{12}$-hydroxyl protons were intramolecularly hydrogen-bonded to the nearby carbonyl oxygen at $C_{11}$ and $C_{1}$, respectively (26). The chemical shifts of the $\mathrm{C}_{10}$ and $\mathrm{C}_{12}$ aromatic enols were 12.1 and $15.0 \mathrm{ppm}$, respectively. $\mathrm{CTC} \times \mathrm{CH}_{3} \mathrm{SO}_{3} \mathrm{H}$ had a signal resonance related to $\mathrm{S}-\mathrm{CH}_{3}$ protons at $2.295 \mathrm{ppm}$. A broad peak was observed at 3-4 ppm for $\mathrm{CTC} \times \mathrm{H}_{2} \mathrm{SO}_{4}$, which indicated the fast exchange rate of free $\mathrm{H}^{+}$from $\mathrm{HSO}_{4}^{-}$ and $\mathrm{H}_{2} \mathrm{O}$.

The UV spectra show that the three salts had the same peaks $\left(\lambda_{\max }\right)$ and troughs $\left(\lambda_{\min }\right)$ (Table I and Fig. S2). The IR spectrum of the $\mathrm{CTC} \times \mathrm{HCl}$ molecule exhibited absorptions associated with the amide group at ring $\mathrm{A}$, the amide III band was at $1672 \mathrm{~cm}^{-1} v(\mathrm{C}=\mathrm{O})$, the amide II band was at $1621 \mathrm{~cm}^{-1} v(\mathrm{~N}-\mathrm{H})$ and the amide III band was at $1413 \mathrm{~cm}^{-1} v(\mathrm{C}=\mathrm{N})$ (Fig. S3). These bands were also observed for the newly synthesized salts at similar wavenumbers, i.e., the $\mathrm{CTC} \times \mathrm{H}_{2} \mathrm{SO}_{4}$ and $\mathrm{CTC} \times \mathrm{CH}_{3} \mathrm{SO}_{3} \mathrm{H}$ amide bands were observed at 1661,1615 , and $1409 \mathrm{~cm}^{-1}$ and $1664,1615,1410 \mathrm{~cm}^{-1}$, respectively. The vibrational bands of hydroxyl and amide $\mathrm{NH}_{2}$ groups were visible at $3305 \mathrm{~cm}^{-1}$, and this was also observed in $\mathrm{CTC} \times \mathrm{H}_{2} \mathrm{SO}_{4}$ and $\mathrm{CTC} \times \mathrm{CH}_{3} \mathrm{SO}_{3} \mathrm{H}$ as a band at 3392 and $3396 \mathrm{~cm}^{-1}$, respectively. The modifications observed in the $\mathrm{CTC} \times \mathrm{H}_{2} \mathrm{SO}_{4}$ and $\mathrm{CTC} \times \mathrm{CH}_{3} \mathrm{SO}_{3} \mathrm{H}$ spectra were similar to those in that of $\mathrm{CTC} \times \mathrm{HCl}$, although the sulfate anions and mesylate anions had unique absorption peaks. The absorption of the antisymmetric stretching vibration of the inorganic $\mathrm{SO}_{4}{ }^{2-}$ group at $1120 \mathrm{~cm}^{-1} v_{\mathrm{a}}\left(\mathrm{SO}_{4}{ }^{2-}\right)$ indicated a strong stretching vibration. On the other hand, symmetric stretching vibration in the wavenumber of $1000-950 \mathrm{~cm}^{-1}$ indicated a weak stretching vi- 
a)

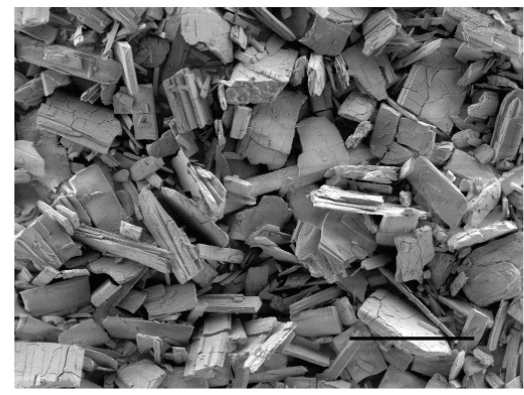

b)

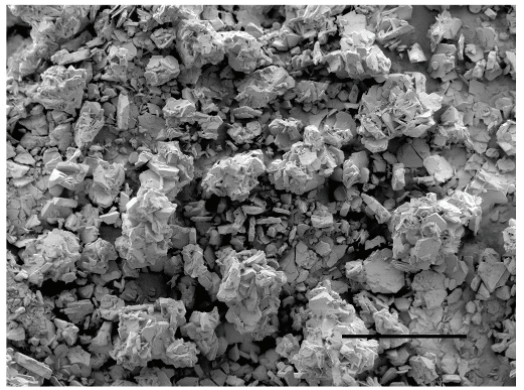

Fig. 2. SEM of: a) $\mathrm{CTC} \times \mathrm{H}_{2} \mathrm{SO}_{4}$ and b) $\mathrm{CTC} \times \mathrm{CH}_{3} \mathrm{SO}_{3} \mathrm{H}$. The scale bar is $100 \mu \mathrm{m}$.

bration. The asymmetric angle vibration and symmetric angle vibration had weak absorptions at 619 and $460 \mathrm{~cm}^{-1}$, respectively. The three oxygen atoms in the mesylate of $\mathrm{CTC} \times \mathrm{CH}_{3} \mathrm{SO}_{3} \mathrm{H}$ were equivalent, but there were antisymmetric stretching vibrations and symmetric stretching vibrations for $\mathrm{SO}_{3}$; the two vibrations were observed at 1206 (strong) and $1047 \mathrm{~cm}^{-1}$ (medium), respectively. The $v(\mathrm{C}-\mathrm{Cl})$ of ring D overlapped with the symmetric stretching vibration of $v\left(\mathrm{SO}_{3}\right)$.

MS has become an effective detection technique due to its high sensitivity and selectivity (27). The fragment of CTC was obtained with the ESI interface in both positive and negative ion modes. The MS fragments of CTCs were investigated in both positive and negative ion modes (Fig. S4 and S5). In positive ion mode, the loss of $\mathrm{NH}_{3}$ and $\mathrm{H}_{2} \mathrm{O}$ from $[\mathrm{M}+\mathrm{H}]^{+}$ions was in agreement with previous studies $(16,28)$. The protonated molecular ions of $\mathrm{CTC} \times \mathrm{HCl}, \mathrm{CTC} \times \mathrm{H}_{2} \mathrm{SO}_{4}$ and $\mathrm{CTC} \times \mathrm{CH}_{3} \mathrm{SO}_{3} \mathrm{H}$ produced three different product ions $\left[\mathrm{M}+\mathrm{H}-\mathrm{NH}_{3}\right]^{+}$at $m / z 462,\left[\mathrm{M}+\mathrm{H}-\mathrm{H}_{2} \mathrm{O}\right]^{+}$at $m / z 461$ and $\left[\mathrm{M}+\mathrm{H}-\mathrm{NH}_{3}-\mathrm{H}_{2} \mathrm{O}\right]^{+}$at $m / z 444$, respectively (Table I and Fig. S6) (29). In negative ion mode, mesylate ions and hydrogen sulfate ions were observed at $\mathrm{m} / \mathrm{z} 95$ and $\mathrm{m} / \mathrm{z} 97$ (Fig. S5), respectively, which demonstrated their presence in the new salts. In CTC, the amide group of ring A can result in a loss of the $\mathrm{NH}_{3}$ group; on the other hand, the $\mathrm{C}_{6}$ position of ring $\mathrm{C}$ can result in a loss of $\mathrm{H}_{2} \mathrm{O}$ because of the lower energy process (30). An elimination reaction can occur between the $\mathrm{C}_{6}$-hydroxyl and $\mathrm{C}_{5 \mathrm{a}}$-proton groups with a loss of $\mathrm{H}_{2} \mathrm{O}$, resulting in an aromatic naphthalene ring structure. It is likely that the presence of the $\mathrm{Cl}$ at position $\mathrm{C}_{7}$ in ring $\mathrm{D}$ rendered the loss of $\mathrm{H}_{2} \mathrm{O}$ from the adjacent $\mathrm{C}_{6}$ position of ring $\mathrm{C}$, which demanded more energy and resulted in a higher abundance of $\left[\mathrm{M}+\mathrm{H}-\mathrm{NH}_{3}\right]^{+}$compared to that of $\left[\mathrm{M}+\mathrm{H}-\mathrm{H}_{2} \mathrm{O}\right]^{+}$for CTC (16). The fragmentation pattern of CTC suggested a loss of the $\mathrm{NH}_{3}$ group first and then a loss of $\mathrm{H}_{2} \mathrm{O}$.

PXRD was used to confirm the formation of the different CTC salts. The PXRD pattern for $\mathrm{CTC} \times \mathrm{HCl}$ was identical to the reported PXRD pattern for polymorphic form $\alpha$ (31). The diffraction peaks of $\mathrm{CTC} \times \mathrm{HCl}, \mathrm{CTC} \times \mathrm{H}_{2} \mathrm{SO}_{4}$ and $\mathrm{CTC} \times \mathrm{CH}_{3} \mathrm{SO}_{3} \mathrm{H}$ are presented in Fig. 3 and Tables S1-3. In the case of the salts, the major peaks were distinctive among $\mathrm{CTC} \times \mathrm{HCl}$, $\mathrm{CTC} \times \mathrm{H}_{2} \mathrm{SO}_{4}$ and $\mathrm{CTC} \times \mathrm{CH}_{3} \mathrm{SO}_{3} \mathrm{H}$. This result was in agreement with the thermal analysis of the salt, indicating the formation of new solid phases.

Fig. 4 shows the results of the DSC and TGA results of the different CTC salts. The small mass loss $(0.69 \%)$ in the temperature range of $25-230{ }^{\circ} \mathrm{C}$ might be attributed to the 


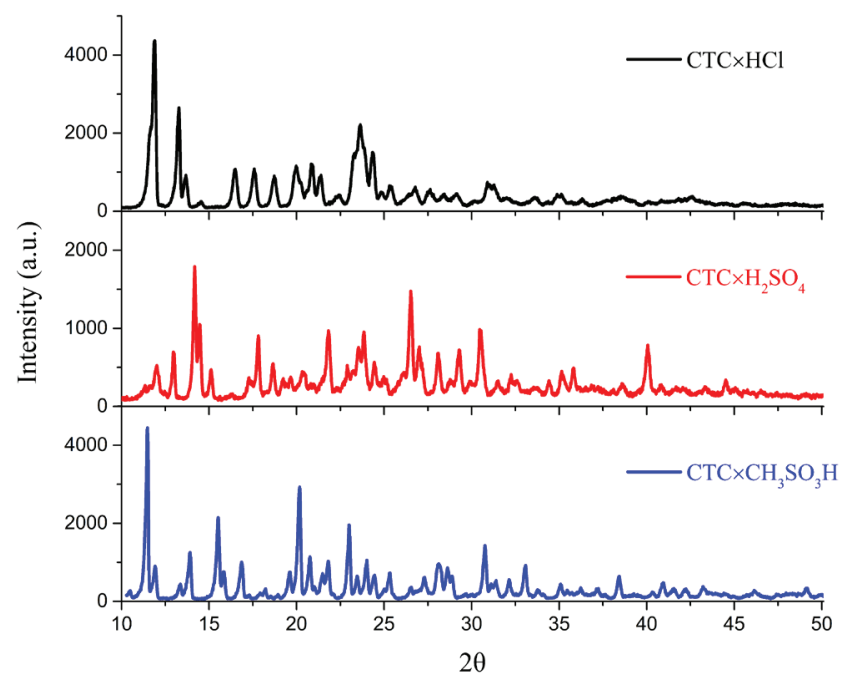

Fig. 3. PXRD of $\mathrm{CTC} \times \mathrm{HCl}, \mathrm{CTC} \times \mathrm{H}_{2} \mathrm{SO}_{4}$ and $\mathrm{CTC} \times \mathrm{CH}_{3} \mathrm{SO}_{3} \mathrm{H}$.

loss of absorbed water and other volatiles. However, degradation was observed in the temperature range of $230-300{ }^{\circ} \mathrm{C}$. Only $58.4 \%$ of the initial mass of $\mathrm{CTC} \times \mathrm{HCl}$ remained at $400{ }^{\circ} \mathrm{C}$. The DSC curve in Fig. 4 a shows that the exothermic peak could be assigned to the decomposition of the CTC structure. The first endothermic peak of $\mathrm{CTC} \times \mathrm{H}_{2} \mathrm{SO}_{4}$ in the DSC curve could be ascribed to dehydration, which could be evidence to prove the presence of water molecules in the $\mathrm{CTC} \times \mathrm{H}_{2} \mathrm{SO}_{4}$ structure. This result was in agreement with those of TGA analysis, which exhibited a mass loss of $3.17 \%$ between 25 and $55{ }^{\circ} \mathrm{C}$ (Fig. $4 \mathrm{~b}$ ). The degradation occurred between 200 and $250{ }^{\circ} \mathrm{C}$, and only $58 \%$ of the initial mass of $\mathrm{CTC} \times \mathrm{H}_{2} \mathrm{SO}_{4}$ remained at $400{ }^{\circ} \mathrm{C}$. For the DSC curve, there was an endothermic event with a melting temperature of $199-202{ }^{\circ} \mathrm{C}$, reflecting the melting of an unhydrated structure of $\mathrm{CTC} \times \mathrm{H}_{2} \mathrm{SO}_{4}$. The consecutive exothermic decomposition event could be assigned to the decomposition of CTC. For $\mathrm{CTC} \times \mathrm{CH}_{3} \mathrm{SO}_{3} \mathrm{H}$, there was also a slight mass loss between 25 and $200{ }^{\circ} \mathrm{C}$, and only $59 \%$ of the initial mass remained at $400{ }^{\circ} \mathrm{C}$ (Fig. 4c). A degradation process was observed in two stages between 200 and $350{ }^{\circ} \mathrm{C}$. The endothermic event at

Table II. The mass fractions of CTC, TC, 4-epiCTC, 4-epiTC and acid determined with HPLC and IC methods

\begin{tabular}{lccccc}
\hline \multirow{2}{*}{ Salt } & \multicolumn{5}{c}{ Mass fraction (\%) } \\
\cline { 2 - 6 } & $\mathrm{CTC}$ & TC & 4-epiCTC & 4-epiTC & Acid (theory) \\
\hline $\mathrm{CTC} \times \mathrm{HCl}$ & $83.91 \pm 1.77$ & $3.18 \pm 0.02$ & $3.01 \pm 0.07$ & $0.06 \pm 0.00$ & $7.14 \pm 0.38(6.86)$ \\
\hline $\mathrm{CTC} \times \mathrm{H}_{2} \mathrm{SO}_{4}$ & $71.69 \pm 2.26$ & $1.67 \pm 0.08$ & $5.46 \pm 0.76$ & $0.11 \pm 0.00$ & $16.55 \pm 2.02(16.16)$ \\
\hline $\mathrm{CTC} \times \mathrm{CH}_{3} \mathrm{SO}_{3} \mathrm{H}$ & $76.76 \pm 1.75$ & $1.40 \pm 0.02$ & $0.87 \pm 0.01$ & 0 & $15.47 \pm 0.48(15.86)$ \\
\hline
\end{tabular}


D. Liu et al.: Synthesis and evaluation of bisulfate/mesylate-conjugated chlortetracycline with high solubility and bioavailability, Acta Pharm. 70 (2020) 483-498.
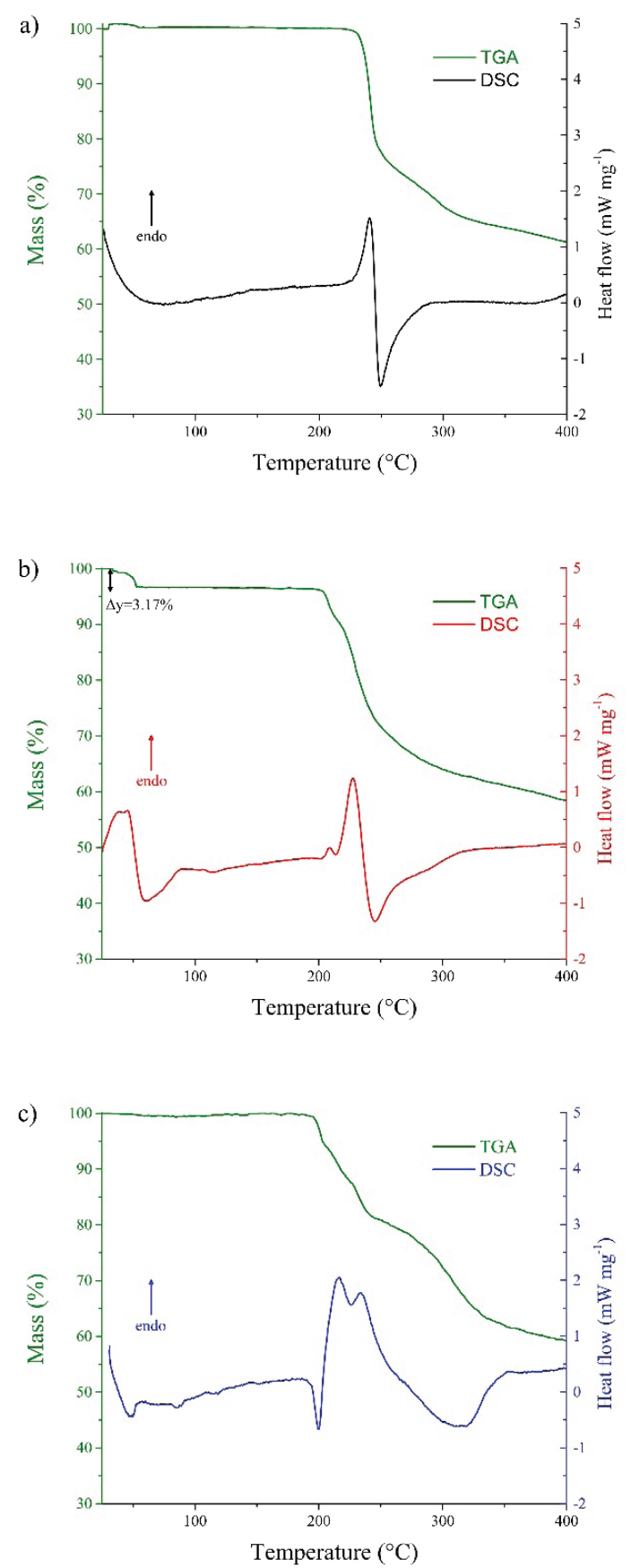

Fig. 4. DSC and TGA curves of: a) $\mathrm{CTC} \times \mathrm{HCl}$, b) $\mathrm{CTC} \times \mathrm{H}_{2} \mathrm{SO}_{4}$ and c) $\mathrm{CTC} \times \mathrm{CH}_{3} \mathrm{SO}_{3} \mathrm{H}$ in an $\mathrm{N}_{2}$ atmosphere. 
199-200 ${ }^{\circ} \mathrm{C}$ could reflect the melting point of $\mathrm{CTC} \times \mathrm{CH}_{3} \mathrm{SO}_{3} \mathrm{H}$. For all of the salts, melting was immediately followed by decomposition. The three CTC salts also had different melting points. The degradation point might confirm the formation of the new salts. Only a $40 \%$ mass loss was observed for the three salts with the same CTC cation by the time the temperature reached $400{ }^{\circ} \mathrm{C}$ under an $\mathrm{N}_{2}$ environment. CTC contains a 4-ring structure and therefore could not be degraded at temperatures up to $400{ }^{\circ} \mathrm{C}$. The thermal degradation of CTC can release dimethylamine, water, isocyanic acid, methane, ammonia and carbon dioxide from the decomposition of isocyanic acid (32). In stoichiometry, the asymmetric unit of $\mathrm{CTC} \times \mathrm{H}_{2} \mathrm{SO}_{4}$ contains a CTC cation, a sulfate anion and one molecule of crystal water. The asymmetric unit of $\mathrm{CTC} \times \mathrm{CH}_{3} \mathrm{SO}_{3} \mathrm{H}$ includes one $\mathrm{CTC}$ cation and one mesylate anion, which suggests that $\mathrm{CTC} \times \mathrm{CH}_{3} \mathrm{SO}_{3} \mathrm{H}$ is an unhydrated $\mathrm{CTC}$ salt.

\section{Quantitation analysis}

HPLC has been successfully used for the quantitation of CTCs in the samples (33). CTC and its derivatives were separated on a C8 column with a retention time of $4.5 \mathrm{~min}$ for 4-epiTC and $5.0 \mathrm{~min}$ for TC (Fig. S7). In contrast, 4-epiCTC and CTC were well separated with retention times of $8.6 \mathrm{~min}$ and $10.1 \mathrm{~min}$, respectively. Table II lists the quantification results for CTCs and their derivatives. The $\omega$ (4-epiCTC) of $\mathrm{CTC} \times \mathrm{H}_{2} \mathrm{SO}_{4}(5.46 \%)$ was higher than that of $\mathrm{CTC} \times \mathrm{HCl}(3.01 \%)$, but the $\omega(\mathrm{TC})$ decreased from $3.18 \%$ for $\mathrm{CTC} \times \mathrm{HCl}$
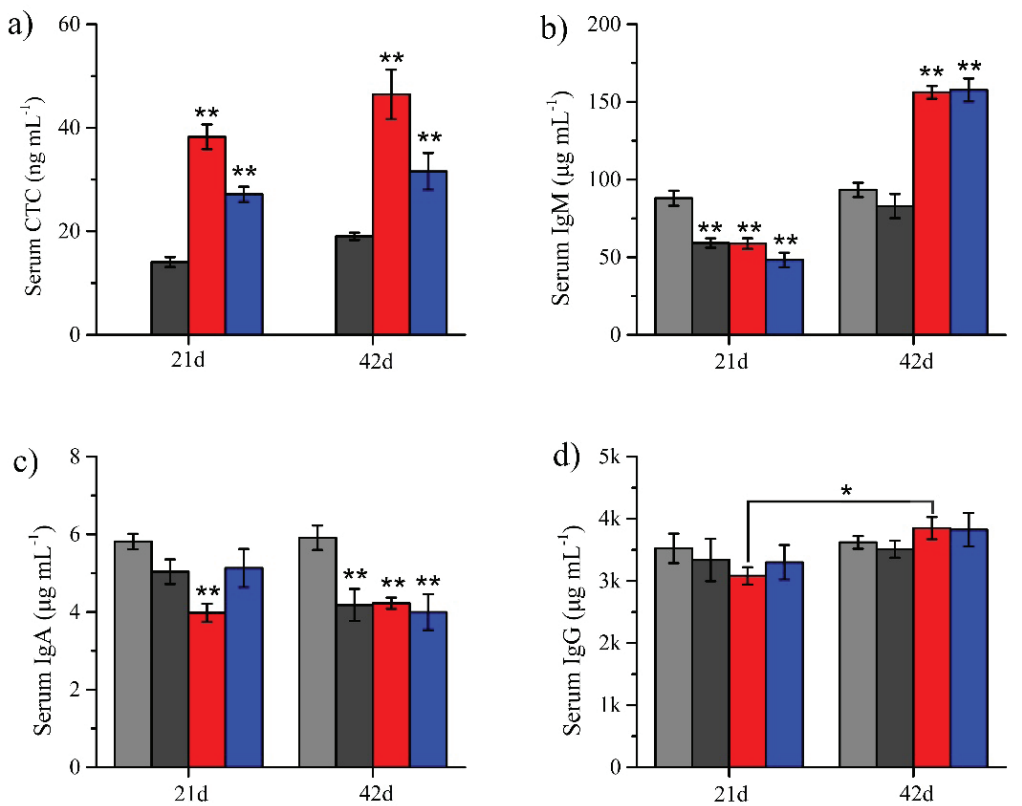

Fig. 5. Effect of oral CTC treatment on serum: a) CTC concentration and b) immunoglobulin IgM, c) IgA and d) IgG) levels in mice. $t$-test: ${ }^{*}$ indicates significant difference $(p<0.05),{ }^{*}$ indicates highly significant difference $(p<0.01)$. 
D. Liu et al:: Synthesis and evaluation of bisulfate/mesylate-conjugated chlortetracycline with high solubility and bioavailability, Acta Pharm. 70 (2020) 483-498.

Table III. The MIC and MBC of CTC salts

\begin{tabular}{lccc}
\hline Bacterial strains & $\begin{array}{c}M I C / M B C \text { for } \\
\mathrm{CTC} \times \mathrm{HCl}\left(\mu \mathrm{mol} \mathrm{mL} \mathrm{mL}^{-1}\right)\end{array}$ & $\begin{array}{c}M I C / M B C \text { for } \\
\mathrm{CTC} \times \mathrm{H}_{2} \mathrm{SO}_{4}\left(\mu \mathrm{mol} \mathrm{mL} \mathrm{mL}^{-1}\right)\end{array}$ & $\begin{array}{c}M I C / M B C \text { for } \\
\mathrm{CTC} \times \mathrm{CH}_{3} \mathrm{SO}_{3} \mathrm{H}\left(\mu \mathrm{mol} \mathrm{mL}^{-1}\right)\end{array}$ \\
\hline Bacillus cereus & $1.05 \times 10^{-4} / 4.18 \times 10^{-4}$ & $1.05 \times 10^{-4} / 4.18 \times 10^{-4}$ & $1.05 \times 10^{-4} / 4.18 \times 10^{-4}$ \\
\hline $\begin{array}{l}\text { Staphylococcus } \\
\text { aureus }\end{array}$ & $8.37 \times 10^{-4} / 6.70 \times 10^{-3}$ & $8.37 \times 10^{-4} / 6.70 \times 10^{-3}$ & $8.37 \times 10^{-4} / 6.70 \times 10^{-3}$ \\
\hline \begin{tabular}{l} 
Escherichia coli \\
\hline
\end{tabular} & $5.36 \times 10^{-2} / 5.36 \times 10^{-2}$ & $5.36 \times 10^{-2} / 5.36 \times 10^{-2}$ & $5.36 \times 10^{-2} / 5.36 \times 10^{-2}$ \\
\hline
\end{tabular}

to $1.67 \%$ for $\mathrm{CTC} \times \mathrm{H}_{2} \mathrm{SO}_{4}$. Moreover, the $\omega\left(4\right.$-epiCTC) of $\mathrm{CTC} \times \mathrm{CH}_{3} \mathrm{SO}_{3} \mathrm{H}(0.87 \%)$ was lower than that of $\mathrm{CTC} \times \mathrm{HCl}(3.01 \%)$, and the $\omega(\mathrm{TC})$ slightly decreased from $3.18 \%$ for $\mathrm{CTC} \times \mathrm{HCl}$ to $1.40 \%$ for $\mathrm{CTC} \times \mathrm{CH}_{3} \mathrm{SO}_{3} \mathrm{H}$. The concentrations of $\omega$ (4-epiTC) in different CTC salts were negligible. Overall, the concentrations of derivatives in $\mathrm{CTC} \times \mathrm{CH}_{3} \mathrm{SO}_{3} \mathrm{H}$ and $\mathrm{CTC} \times \mathrm{H}_{2} \mathrm{SO}_{4}$ were all decreased, but the 4-epiCTC in $\mathrm{CTC} \times \mathrm{H}_{2} \mathrm{SO}_{4}$ was slightly higher. The linearity of the chromatographic procedure was checked by analyzing a CTC reference substance in the concentration range of $0.1-2 \mathrm{mg} \mathrm{mL}^{-1}$. The correlation coefficients of the calibration curves were above 0.99 , indicating a linear calibration curve.

IC with high sensitivity is suitable for the analysis of anions (the hydrochloride ion, sulfate ion and mesylate ion) at low concentrations in samples $(34,35)$. The anions chloride, sulfate and mesylate were separated with retention times of 3.8, 4.8 and $3.2 \mathrm{~min}$, respectively (Fig. S8). The resolution for the three peaks was good. The results showed that there was only one anion in each of the $\mathrm{CTC} \times \mathrm{H}_{2} \mathrm{SO}_{4}$ and $\mathrm{CTC} \times \mathrm{CH}_{3} \mathrm{SO}_{3} \mathrm{H}$ products. Linearity was evaluated for chloride, sulfate and mesylate in the range of $5-40 \mu \mathrm{g} \mathrm{mL}^{-1}(y=0.0945 x-0.0532$, $R^{2}=0.9987 ; y=0.0999 x-0.1338, R^{2}=0.9993$ and $y=0.0423 x-0.056, R^{2}=0.9997$, respectively).

In this paper, we measured the anion concentration of different CTC salts. The results showed that the percentages of acid in terms of mass for $\mathrm{CTC} \times \mathrm{HCl}, \mathrm{CTC} \times \mathrm{H}_{2} \mathrm{SO}_{4}$ and $\mathrm{CTC} \times \mathrm{CH}_{3} \mathrm{SO}_{3} \mathrm{H}$ were $7.14,16.55$ and $15.47 \%$, respectively, which was in agreement with the theoretical anion composition of the different CTC salts. As a result, it was reasonable to conclude that the molar ratios of $\mathrm{CTC}$ to acid in $\mathrm{CTC} \times \mathrm{H}_{2} \mathrm{SO}_{4}$ and $\mathrm{CTC} \times \mathrm{CH}_{3} \mathrm{SO}_{3} \mathrm{H}$ were 1:1 and 1:1, respectively.

The solubility of $\mathrm{CTC} \times \mathrm{HCl}, \mathrm{CTC} \times \mathrm{H}_{2} \mathrm{SO}_{4}$ and $\mathrm{CTC} \times \mathrm{CH}_{3} \mathrm{SO}_{3} \mathrm{H}$ in the water at $25^{\circ} \mathrm{C}$ was measured and is outlined in Table I. The table shows that $\mathrm{CTC} \times \mathrm{H}_{2} \mathrm{SO}_{4}$ and $\mathrm{CTC} \times \mathrm{CH}_{3} \mathrm{SO}_{3} \mathrm{H}$ were more soluble in water than $\mathrm{CTC} \times \mathrm{HCl}$. The table also shows a significant difference in the solubility among $\mathrm{CTC} \times \mathrm{HCl}, \mathrm{CTC} \times \mathrm{H}_{2} \mathrm{SO}_{4}$ and $\mathrm{CTC} \times \mathrm{CH}_{3} \mathrm{SO}_{3} \mathrm{H}(p<0.01)$.

\section{Biological evaluation}

The MIC and $\mathrm{MBC}$ of $\mathrm{CTC} \times \mathrm{HCl}, \mathrm{CTC} \times \mathrm{H}_{2} \mathrm{SO}_{4}$ and $\mathrm{CTC} \times \mathrm{CH}_{3} \mathrm{SO}_{3} \mathrm{H}$ are outlined in Table III. The three salts had the same MIC for Bacillus cereus, Staphylococcus aureus and Escherichia coli, and the concentrations were $1.05 \times 10^{-4}, 8.37 \times 10^{-4}$ and $5.36 \times 10^{-2} \mu \mathrm{mol} \mathrm{mL}^{-1}$, respectively. Interestingly, the MBC of the three salts for Escherichia coli was the same as the MIC. This could demonstrate that the Escherichia coli had been dead after $24 \mathrm{~h}$ of incubation. 
D. Liu et al.: Synthesis and evaluation of bisulfate/mesylate-conjugated chlortetracycline with high solubility and bioavailability, Acta Pharm. 70 (2020) 483-498.

We measured the concentration of CTCs in mouse serum after 21 and 42 days. The results showed that the CTC concentrations in serum collected from mice treated with $\mathrm{CTC} \times \mathrm{H}_{2} \mathrm{SO}_{4}$ and $\mathrm{CTC} \times \mathrm{CH}_{3} \mathrm{SO}_{3} \mathrm{H}$ were significantly higher than those treated with $\mathrm{CTC} \times \mathrm{HCl}$ at both 21 and 42 days (Fig. 5a). This demonstrated that $\mathrm{CTC} \times \mathrm{H}_{2} \mathrm{SO}_{4}$ and $\mathrm{CTC} \times \mathrm{CH}_{3} \mathrm{SO}_{3} \mathrm{H}$ had better bioavailability due to their higher solubility than that of $\mathrm{CTC} \times \mathrm{HCl}$. No CTCs were found in the control group. Linearity was evaluated with CTC concentrations in the range of $0.05-1.6 \mathrm{ng} \mathrm{mL}^{-1}\left(y=-33.309 x+33.938, R^{2}=0.9967\right)$.

Considering that antibiotics could influence the immunity of organisms, the IgM, IgA and IgG levels in serum were evaluated after the mice were treated with CTCs. The results showed that the concentrations of the IgM antibody in the treated groups were lower than in the control group after 21 days $(p<0.01)$ (Fig. 5b). Interestingly, the IgM antibody concentrations in the groups treated with $\mathrm{CTC} \times \mathrm{H}_{2} \mathrm{SO}_{4}$ and $\mathrm{CTC} \times \mathrm{CH}_{3} \mathrm{SO}_{3} \mathrm{H}$ significantly increased compared with that in the control group, and the $\mathrm{CTC} \times \mathrm{HCl}$-treated group showed similar results after administration for 42 consecutive days $(p<0.01)$. The IgM antibody concentration in the $\mathrm{CTC} \times \mathrm{HCl}$-treated group increased to normal levels without a significant change compared with that of the control group $(p>0.05)$. The IgA antibody concentrations in the $\mathrm{CTC} \times \mathrm{H}_{2} \mathrm{SO}_{4}$ treated group was lower than that in the control group $(p<0.01)$ after 21 days, but the IgA antibody concentrations in the $\mathrm{CTC} \times \mathrm{HCl}-$ and $\mathrm{CTC} \times \mathrm{CH}_{3} \mathrm{SO}_{3} \mathrm{H}-$ -treated groups showed no obvious reduction compared with that in the control group $(p$ $>0.05$ ) (Fig. 5c). However, the IgA antibody concentration in all three treated groups decreased significantly $(p<0.01)$ after 42 days compared with that in the control group. Considering the negative effects of sustaining a low dose of CTC salts, the significant decrease in IgA antibody concentration after 21 days for the $\mathrm{CTC} \times \mathrm{H}_{2} \mathrm{SO}_{4}$-treated group might have resulted from the high serum CTC concentration. The IgG antibody concentration in all treated groups was not significantly different from that in the control group after 21 and 42 days ( $p>0.05$ ) (Fig. $5 d$ ). Interestingly, the IgG antibody concentration in the $\mathrm{CTC} \times \mathrm{H}_{2} \mathrm{SO}_{4}{ }^{-}$ treated group showed an increase from 21 to 42 days $(p<0.05)$. The immunoglobulin standard curves were made with four parameters logistic curve fitting, and the correlation coefficients of the calibration curves were above 0.99 . The standard curves of IgM, IgA and $\operatorname{IgG}$ were $y=9.74206+(0.02568-9.74206) /\left(1+(x / 1402.73488)^{\wedge} 0.88258\right), R^{2}=0.99943 ; y=1.4652$ $+(-20.19055-1.4652) /\left(1+(x / 0.24642)^{\wedge} 0.85859\right), R^{2}=0.99687$ and $y=4.80936+(0.03013-$ $4.80936) /\left(1+(x / 206.13394)^{\wedge} 0.86599\right), R^{2}=0.99897$, respectively.

TCs could inhibit the acquired immune system and innate immune system defenses, such as phagocytes and complement, T and B lymphocytes (36). Nikolov et al. (37) found that TCs inhibit immunoglobulin antibody formation in spleen cells, especially when treated with CTCs. In accordance with their results, the concentrations of IgM and IgA antibodies in serum collected from the treated groups both decreased after 21 days, which suggested that immunocompetence for antibodies in mice could be decreased by CTCs. Our results also showed that the concentration of IgM significantly increased in both the $\mathrm{CTC} \times \mathrm{H}_{2} \mathrm{SO}_{4}$-treated group and the $\mathrm{CTC} \times \mathrm{CH}_{3} \mathrm{SO}_{3} \mathrm{H}$-treated group after 42 days compared to that of the control group. In contrast, the IgA concentration had a further reduction after 42 days. The change in IgG concentration was not obvious during the whole treatment duration. In addition, $\mathrm{CTC} \times \mathrm{H}_{2} \mathrm{SO}_{4}$ and $\mathrm{CTC} \times \mathrm{CH}_{3} \mathrm{SO}_{3} \mathrm{H}$ had higher bioavailability than that of $\mathrm{CTC} \times \mathrm{HCl}$. Overall, the modulation of IgM, IgA and IgG antibodies by supplementation with CTCs might be related to physical health and production parameters. 


\section{CONCLUSIONS}

This study set out to improve the solubility and bioavailability of CTC, and CTC $\times \mathrm{H}_{2} \mathrm{SO}_{4}$ (CTC: $\left.\mathrm{H}_{2} \mathrm{SO}_{4}: \mathrm{H}_{2} \mathrm{O}=1: 1: 1\right)$ and $\mathrm{CTC} \times \mathrm{CH}_{3} \mathrm{SO}_{3} \mathrm{H}\left(\mathrm{CTC}: \mathrm{CH}_{3} \mathrm{SO}_{3} \mathrm{H}=1: 1\right)$ were synthesized, whose molecular ratio and structure were also characterized. HPLC and IC chromatography were used to analyze the cation and anion concentrations in the new salts, and the results further confirmed the mole ratio of CTC to the salt anion. The thermal analysis confirmed that $\mathrm{CTC} \times \mathrm{H}_{2} \mathrm{SO}_{4}$ had one mole of crystal water and $\mathrm{CTC} \times \mathrm{CH}_{3} \mathrm{SO}_{3} \mathrm{H}$ had no water in their new salts. The PXRD results demonstrated that $\mathrm{CTC} \times \mathrm{H}_{2} \mathrm{SO}_{4}$ and $\mathrm{CTC} \times \mathrm{CH}_{3} \mathrm{SO}_{3} \mathrm{H}$ were new crystals. The solubility of $\mathrm{CTC} \times \mathrm{H}_{2} \mathrm{SO}_{4}$ and $\mathrm{CTC} \times \mathrm{CH}_{3} \mathrm{SO}_{3} \mathrm{H}$ improved by 53 and 44 times in water, respectively, when compared with that of $\mathrm{CTC} \times \mathrm{HCl}$. The CTC concentrations in serum collected from the treated mice were significantly increased in both the $\mathrm{CTC} \times \mathrm{H}_{2} \mathrm{SO}_{4}$ - and $\mathrm{CTC} \times \mathrm{CH}_{3} \mathrm{SO}_{3} \mathrm{H}$-treated groups compared to that in the $\mathrm{CTC} \times \mathrm{HCl}$-treated group, which indicated improvement of their bioavailability. In addition, the $\mathrm{CTC} \times \mathrm{H}_{2} \mathrm{SO}_{4}-$ and $\mathrm{CTC} \times \mathrm{CH}_{3} \mathrm{SO}_{3} \mathrm{H}$-treated groups exhibited a strong immune response. In conclusion, our results suggest that $\mathrm{CTC} \times \mathrm{H}_{2} \mathrm{SO}_{4}$ and $\mathrm{CTC} \times \mathrm{CH}_{3} \mathrm{SO}_{3} \mathrm{H}$ are more effective than $\mathrm{CTC} \times \mathrm{HCl}$, although there is no difference between their antibiotic activities. Evaluation of their bioavailability, pharmacology and toxicology should be completed in experiments with poultry and livestock model animals.

Acknowledgements. - This work was financially supported by the Foundation and Advanced Research Project of CQ CSTC (2013jjB0011), Fund Project for Transformation of Scientific and Technological Achievements from the Ministry of Science and Technology (2014KXWQT071242) and Social programs and human security from Chongqing science and technology innovation projects (Cstc2017shms-xdny0033, Cstc2017shms-xdny80006).

Supplementary materials are available upon request.

\section{REFERENCES}

1. B. M. Duggar, Aureomycin - a product of the continuing search for new antibiotics, Ann. N.Y. Acad. Sci. 51 (1948) 177-181; https://doi.org/10.1111/j.1749-6632.1948.tb27262.x

2. T. H. Jukes, Some historical notes on chlortetracycline, J. Infect. Dis. 7 (1985) 702-707; https://doi. org/10.1093/clinids/7.5.702

3. A. Garmyn, M. Vereecken, K. Degussem, W. Depondt, F. Haesebrouck and A. Martel, Efficacy of tiamulin alone or in combination with chlortetracycline against experimental Mycoplasma gallisepticum infection in chickens, Poult Sci. 96 (2017) 3367-3374; https://doi.org/10.3382/ps/pex105

4. X. Wu, Y. Wei, J. Zheng, X. Zhao and W. Zhong, The behavior of tetracyclines and their degradation products during swine manure composting, Bioresour. Technol. 102 (2011) 5924-5931; https://doi. org/10.1016/j.biortech.2011.03.007

5. A. Gajda and A. Posyniak, Liquid chromatography - tandem mass spectrometry method for the determination of ten tetracycline residues in muscle samples, Bull. Vet. Pulawy. 59 (2015) 345-352; https://doi.org/10.1515/bvip-2015-0051

6. H. H. E. Williams, M. D. Tokach, S. S. Dritz, J. C. Woodworth, J. M. DeRouchey, R. G. Amachawadi, T. G. Nagaraja and R. D. Goodband, Effects of feeding probiotic or chlortetracycline or a combination on nursery pig growth performance, J. Anim. Sci. 95 (2017) 81-82; https://doi.org/10.2527/ asasmw.2017.12.172

7. E. R. Campagnolo, K. R. Johnson, A. Karpati, C. S. Rubin, D. W. Kolpin, M. T. Meyer, J. E. Esteban, R. W. Currier, K. Smith, K. M. Thu and M. McGeehin, Antimicrobial residues in animal waste and 
D. Liu et al: Synthesis and evaluation of bisulfate/mesylate-conjugated chlortetracycline with high solubility and bioavailability, Acta Pharm. 70 (2020) 483-498.

water resources proximal to large-scale swine and poultry feeding operations, Sci. Total. Environ. 299 (2002) 89-95; https://doi.org/10.1016/s0048-9697(02)00233-4

8. D. P. Elder, R. Holm and H. L. de Diego, Use of pharmaceutical salts and cocrystals to address the issue of poor solubility, Int. J. Pharm. 453 (2013) 88-100; https://doi.org/10.1016/j.ijpharm.2012.11.028

9. N. Parisi, P. J. Matts, R. Lever, J. Hadgraft and M. E. Lane, Preparation and characterisation of hexamidine salts, Int. J. Pharm. 493 (2015) 404-411; https://doi.org/10.1016/j.ijpharm.2015.07.071

10. C. Florindo, A. Costa, C. Matos, S. L. Nunes, A. N. Matias, C. M. M. Duarte, L. P. N. Rebelo, L. C. Branco and I. M. Marrucho, Novel organic salts based on fluoroquinolone drugs: Synthesis, bioavailability and toxicological profiles, Int. J. Pharm. 469 (2014) 179-189; https://doi.org/10.1016/j. ijpharm.2014.04.034

11. W. Guerra, E. D. Azevedo, A. R. D. Monteiro, M. Bucciarelli-Rodriguez, E. Chartone-Souza, A. M. A. Nascimento, A. P. S. Fontes, L. Le Moyec and E. C. Pereira-Maia, Synthesis, characterization, and antibacterial activity of three palladium(II) complexes of tetracyclines, J. Inorg. Biochem. 99 (2005) 2348-2354; https://doi.org/10.1016/j.jinorgbio.2005.09.001

12. D. Fernandez-Calvino, A. Bermudez-Couso, M. Arias-Estevez, J. C. Novoa-Munoz, M. J. FernandezSanjurjo, E. Alvarez-Rodriguez and A. Nunez-Delgado, Kinetics of tetracycline, oxytetracycline, and chlortetracycline adsorption and desorption on two acid soils, Environ. Sci. Pollut. Res. 22 (2015) 425-433; https://doi.org/10.1007/s11356-014-3367-9

13. S. Aitipamula, A. B. H. Wong, P. S. Chow and R. B. H. Tan, Pharmaceutical Salts of Haloperidol with Some Carboxylic Acids and Artificial Sweeteners: Hydrate Formation, Polymorphism, and Physicochemical Properties, Cryst. Growth Des. 14 (2014) 2542-2556; https://doi.org/10.1021/cg500245e

14. A. O. Surov, A. N. Manin, A. P. Voronin, K. V. Drozd, A. A. Simagina, A. V. Churakov and G. L. Perlovich, Pharmaceutical salts of ciprofloxacin with dicarboxylic acids, Eur. J. Pharm. Sci. 77 (2015) 112-121; https://doi.org/10.1016/j.ejps.2015.06.004

15. G. Zurhelle, M. Petz, E. Mueller-Seitz and E. Siewert, Metabolites of oxytetracycline, tetracycline, and chlortetracycline and their distribution in egg white, egg yolk, and hen plasma, J. Agric. Food. Chem. 48 (2000) 6392-6396; https://doi.org/10.1021/jf000141k

16. M. Cherlet, M. Schelkens, S. Croubels and P. De Backer, Quantitative multi-residue analysis of tetracyclines and their 4-epimers in pig tissues by high-performance liquid chromatography combined with positive-ion electrospray ionization mass spectrometry, Anal. Chim. Acta. 492 (2003) 199-213; https://doi.org/10.1016/s0003-2670(03)00341-6

17. A. L. Cinquina, F. Longo, G. Anastasi, L. Giannetti and R. Cozzani, Validation of a high-performance liquid chromatography method for the determination of oxytetracycline, tetracycline, chlortetracycline and doxycycline in bovine milk and muscle, J. Chromatogr. A. 987 (2003) 227-233; https:// doi.org/10.1016/s0021-9673(02)01446-2

18. A. Posyniak, K. Mitrowska, J. Zmudzki and J. Niedzielska, Analytical procedure for the determination of chlortetracycline and 4-epi-chlortetracycline in pig kidneys, J. Chromatogr. A. 1088 (2005) 169-174; https://doi.org/10.1016/j.chroma.2005.01.007

19. A. Anadon, F. Gamboa, M. Aranzazu Martinez, V. Castellano, M. Martinez, I. Ares, E. Ramos, F. H. Suarez and M. Rosa Martinez-Larranaga, Plasma disposition and tissue depletion of chlortetracycline in the food producing animals, chickens for fattening, Food Chem. Toxicol. 50 (2012) 2714-2721; https://doi.org/10.1016/j.fct.2012.05.007

20. K. Kodimalar, R. A. Rajini, S. Ezhilvalavan and G. Sarathchandra, A survey of chlortetracycline concentration in feed and its residue in chicken egg in commercial layer farms, J. Biosci. 39 (2014) 425-431; https://doi.org/10.1007/s12038-014-9425-0

21. K. Washburn, V. R. Fajt, P. Plummer, J. F. Coetzee, L. W. Wulf and S. Washburn, Pharmacokinetics of oral chlortetracycline in nonpregnant adult ewes, J. Vet. Pharmacol. Ther. 37 (2014) 607-610; https:// doi.org/10.1111/jvp.12144

22. D. A. Bair, I. E. Popova, K. W. Tate and S. J. Parikh, Transport of oxytetracycline, chlortetracycline, and ivermectin in surface runoff from irrigated pasture, J. Environ. Sci. Health, Part B. 52 (2017) 631-640; https://doi.org/10.1080/03601234.2017.1330069 
23. H. S. Chung, Y.-J. Lee, M. M. Rahman, A. M. Abd El-Aty, H. S. Lee, M. H. Kabir, S. Kim, B.-J. Park, J.-E. Kim, F. Hacimuftuoglu, N. Nahar, H.-C. Shin and J.-H. Shim, Uptake of the veterinary antibiotics chlortetracycline, enrofloxacin, and sulphathiazole from soil by radish, Sci. Total Environ. 605 (2017) 322-331; https://doi.org/10.1016/j.scitotenv.2017.06.231

24. C. Schwake-Anduschus and G. Langenkamper, Chlortetracycline and related tetracyclines: detection in wheat and rye grain, J. Sci. Food Agric. 98 (2018) 4542-4549; https://doi.org/10.1002/jsfa.8982

25. A. Molaei, A. Lakzian, R. Datta, G. Haghnia, A. Astaraei, M. Rasouli-Sadaghiani and M. T. Ceccherini, Impact of chlortetracycline and sulfapyridine antibiotics on soil enzyme activities, Int. Agrophys. 31 (2017) 499-505; https://doi.org/10.1515/intag-2016-0084

26. A. F. Casy and A. Yasin, The identification and stereochemical study of tetracycline antibiotics by $1 \mathrm{H}$ nuclear magnetic resonance spectroscopy, J. Pharm. Biomed. Anal. 1 (1983) 281-292; https://doi. org/10.1016/0731-7085(83)80040-5

27. Z. Huang, R. Francis, Y. Zha and J. Ruan, Development of a simple method for quantitation of methanesulfonic acid at low ppm level using hydrophilic interaction chromatography coupled with ESI-MS, J. Pharm. Biomed. Anal. 102 (2015) 17-24; https://doi.org/10.1016/j.jpba.2014.08.019

28. J. Zhu, D. D. Snow, D. A. Cassada, S. J. Monson and R. F. Spalding, Analysis of oxytetracycline, tetracycline, and chlortetracycline in water using solid-phase extraction and liquid chromatographytandem mass spectrometry, J. Chromatogr. A. 928 (2001) 177-186; https://doi.org/10.1016/s00219673(01)01139-6

29. M. H. Khan, H. Bae and J.-Y. Jung, Tetracycline degradation by ozonation in the aqueous phase: Proposed degradation intermediates and pathway, J. Hazard. Mater. 181 (2010) 659-665; https://doi. org/10.1016/j.jhazmat.2010.05.063

30. A. M. Kamel, H. G. Fouda, P. R. Brown and B. Munson, Mass spectral characterization of tetracyclines by electrospray ionization, H/D exchange, and multiple stage mass spectrometry, J. Am. Soc. Mass. Spectrom. 13 (2002) 543-557; https://doi.org/10.1016/s1044-0305(02)00356-2

31. S. Miyazaki, T. Arita, R. Hori and K. Ito, Effect of polymorphism on dissolution behavior and gastrointestinal absorption of chlortetracycline hydrochloride, Chem. Pharm. Bull. 22 (1974) 638-642; https://doi.org/10.1248/cpb.22.638

32. P. Cervini, L. C. Murreli Machado, A. P. Garcia Ferreira, B. Ambrozini and E. T. Gomes Cavalheiro, Thermal decomposition of tetracycline and chlortetracycline, J. Anal. Appl. Pyrolysis. 118 (2016) 317-324; https://doi.org/10.1016/j.jaap.2016.02.015

33. J. Diana, L. Vandenbosch, B. De Spiegeleer, J. Hoogmartens and E. Adams, Evaluation of the stability of chlortetracycline in granular premixes by monitoring its conversion into degradation products, J. Pharm. Biomed. Anal. 39 (2005) 523-530; https://doi.org/10.1016/j.jpba.2005.04.030

34. O. Quattrocchi, L. Frisardi, M. Iglesias, M. Noya, M. Caputto, D. Ferraris, D. Siliprandi and E. Piccinni, Ion exchange chromatographic determination of olpadronate, phosphate, phosphite, chloride and methanesulfonic acid, J. Pharm. Biomed. Anal. 24 (2001) 1011-1018; https://doi.org/10.1016/s07317085(00)00535-5

35. S.-I. Ohira and K. Toda, Ion chromatographic measurement of sulfide, methanethiolate, sulfite and sulfate in aqueous and air samples, J. Chromatogr. A. 1121 (2006) 280-284; https://doi.org/10.1016/j. chroma.2006.05.074

36. M. T. Labro, Immunomodulation by antibacterial agents-Is it clinically relevant, Drugs 45 (1993) 319-328; https://doi.org/10.2165/00003495-199345030-00001

37. T. Nikolov, K. Berchev and A. Ilkov, Protein pattern in the blood serum of rabbits treated with chlortetracycline, Tr. Vissh. Med. Inst. 41 (1962) 41-48. 